\title{
ANALISIS PENGUKURAN KINERJA REKSA DANA SAHAM DENGAN METODE RISK-ADJUSTED RETURN DI BURSA EFEK INDONESIAPERIODE TAHUN 2011-2013
}

\author{
Datu Pinastiko Adi Email: dha_two@yahoo.co.id \\ Musaroh, M.Si, Email: musaroh@uny.ac.id \\ Fakultas Ekonomi Universitas Negeri Yogyakarta
}

\begin{abstract}
This study aimed to investigate the performances of the equity funds based on Risk-Adjusted Return using Sharpe, Treynor, Jensen, $M^{\wedge} 2$ and Information Ratio methods along with comparison between the performances of the equity funds and benchmark performance in research periods. The data analysis methods were Sharpe, Treynor, Jensen, $M^{\wedge} 2$ and Information Ratio methods. The data analysis using Sharpe and Treynor methods produced the same results; In 2011 there are 20 equity funds with positive performances. In 2012 there are 42 equity funds with positive performance, and in 20136 equity funds with positive performance. According to Jensen method, in 2011 there are 19 equity funds with positive performance. In 2012 there are 12 equity funds with positive performances. Meanwhile, in 201319 equity funds with positive performance. According to $M^{\wedge} 2$ method, in 2011 there are 19 equity funds with positive performance. In 2012 there are 12 equiy funds with positive perfomance. Meanwhile, in 201323 equity funds with positive performance. According to Information Ratio method, in 2011 there are 19 equity funds with positive performance. In 2012 there are 12 equity funds with positive performance. Meanwhile, in 201319 equity funds with positive performance. The results of the comparison between the performances of the equity funds to benchmark show that in 2011, 18 equity funds had performances above the benchmark performance (outperform), in 2012, 13 equity funds had performances above the benchmark performance (outperform). Meanwhile, in 2013 there are 16 equity funds had performance above the benchmark performance (outperform).
\end{abstract}

Keywords:Risk-Adjusted Return, Sharpe, Treynor, Jensen, $M^{\wedge} 2$ and Information Ratio

\section{Pendahuluan}

Investasi tidak langsung melalui investment companies (Reksa Dana) sebagai intermediasi keuangan sedang berkembang pesat. Reksa Dana saham merupakan jenis Reksa Dana yang paling banyak diminati, suatu wadah yang digunakan untuk menghimpun dana investor yang selanjutnya diinvestasikan dalam portofolio berbagai jenis saham oleh manajer investasi. Perkembangan pesat ini ditinjau dari keunggulan Reksa Dana saham terutama, skala ekonomis dalam akses ke pasar saham dan diversifikasi investasi, manajer investasi yang profesional, dan return yang paling 
tinggi dibandingkan dengan Reksa Dana jenis lain (Wibowo, 2005). Sehingga, Reksa Dana saham merupakan sebuah solusi bagi masyarakat yang tidak memiliki pengetahuan tentang analisis investasi tetapi ingin berinvestasi pada pasar saham dengan dana terjangkau. Meskipun begitu investasi di Reksa Dana saham bukan berarti tidak berisiko, masih banyak investor yang belum mengetahui hubungan antara return dan risiko, kebanyakan dari mereka hanya membentuk portofolio Reksa Dana secara acak tanpa melakukan analisis terlebih dahulu. Mereka terlalu percaya pada manajer investasi yang mengelola dana mereka. Diperlukan analisis pengukuran untuk mengetahui baik atau tidaknya suatu Reksa Dana saham sehingga investor dapat selalu memperoleh return yang optimal dengan risiko terendah.

Terdapat lima jenis Reksa Dana yang terdapat di Bapepam-LK yaitu Reksa Dana pasar uang, Reksa Dana pendapatan tetap, Reksa Dana saham, Reksa Dana campuran dan Reksa Dana terproteksi. Investor dapat memilih alokasi dananya berdasarkan instrumen pasar modal sesuai dengan tingkat risiko dan return yang diinginkan. Perkembangan Reksa Dana di Indonesia dari tahun ke tahun terus meningkat terutama pada komponen Reksa Dana saham yang dapat terlihat dari meningkatnya IHSG dari tahun ke tahun. Dari lima kategori jenis
Reksa Dana di atas Reksa Dana saham merupakan kategori jenis Reksa Dana yang paling diminati oleh investor karena menghasilkan tingkat return yang tinggi tetapi juga memberikan tingkat risiko yang paling tinggi dan tingkat ketidakpastian yang tinggi dibandingkan kategori jenis lain. Sehingga, perlu dilakukan pengukuran kinerja Reksa Dana sehingga dapat diketahui perbandingan antara tingkat risiko dan return dari Reksa Dana yang diterima oleh investor.

Reksa Dana dikelola oleh Manajer investasi (Investment Manager). Secara logika bahwa return yang dihasilkan oleh manajer investasi tersebut tentu akan lebih baik dari return pasar (Amalia, 1999). Beberapa peneliti terdahulu mengemukakan hasil penelitiannya, bahwa kinerja Reksa Dana (Mutual Fund Performance) yang dikelola manajer investasi tidak selalu berada diatas Kinerja pasar (market performance), akan tetapi ada pula sebaliknya mengatakan bahwa bila dikelola secara maksimal akan menghasilkan return Reksa Dana diatas return pasar (Rantetonding, 2002). Untuk mengetahui Reksa Dana yang optimal harus dilakukan pengukuran kinerja Reksa Dana. Kinerja Reksa Dana adalah kemampuan dari Reksa Dana untuk memberikan return tertentu sesuai dengan tingkat risiko tertentu. 
Pengukuran yang digunakan untuk menilai kinerja Reksa Dana dalam penelitian ini adalah pengukuran kinerja Reksa Dana berdasarkan Risk-Adjusted Return yang merupakan penilaian dengan mengkombinasikan tingkat return dan risiko, seberapa besar return yang dihasilkan akan dibandingkan pula dengan tingkat risiko yang diterima. Penelitian ini menggunakan Risk-Adjusted Return dengan metode Sharpe Ratio, Treynor Ratio, Jensen, $M^{2}$ dan Information Ratio dengan proxy return IHSG yang dijadikan benchmark karena obyek penelitian merupakan Reksa Dana saham yang $80 \%-100 \%$ proporsi dananya dialokasikan pada instrumen pasar saham. Dengan demikian dari masingmasing metode dapat diketahui hasil kinerja Reksa Dana. Sehingga, dari data yang dihasilkan dapat dijadikan sebagai pedoman bagi para investor untuk menentukan Reksa Dana saham mana yang akan dimasukkan ke dalam portofolionya.

Penelitian ini juga membandingkan hasil kinerja Reksa Dana saham dengan kinerja benchmark (IHSG) untuk mengetahui Reksa Dana saham yang termasuk outperform maupun underperform. Reksa Dana saham dinyatakan outperform apabila melebihi kinerja benchmark dan apabila kinerja Reksa Dana saham dibawah kinerja benchmark maka Reksa Dana saham dinyatakan underperform.

Data yang digunakan dalam penelitian ini adalah NAB mingguan dan IHSG selama tiga tahun yang dimulai dari tanggal 7 Januari 2011 sampai dengan penutupan akhir tahun yaitu tanggal 27 Desember 2013. Reksa Dana saham merupakan salah satu jenis investasi yang fluktuatif jadi semakin banyak periode penelitian akan mempengaruhi keakuratan data yang dihasilkan. Namun, perusahaan Reksa Dana saham selalu mengalami perubahan setiap tahunnya. Sehingga, dari pertimbangan jumlah sampel yang semakin sedikit dikarenakan terlalu lama memilih periode maka peneliti memilih rentang waktu yang tidak terlalu lama (3 tahun) agar dapat memperoleh jumlah sampel yang tidak terlalu sedikit dan dapat sesuai dengan apa yang dibutuhkan investor.

Beberapa hasil penelitian terdahulu terhadap Reksa Dana saham dilakukan oleh Siahaan (2006) dan pada jangka waktu 5 tahun yaitu periode 2001-2005 menyatakan bahwa dari 7 Reksa Dana saham yang dijadikan sampel hanya terdapat 3 Reksa Dana saham yang mampu outperform berdasarkan metode Jensen. Saraswati (2006) juga dalam penelitiannya yang bertujuan untuk mengetahui apakah return dan risiko Reksa Dana saham lebih baik daripada return pasar(LQ-45) dan apakah ada 
pengaruh positif antara rata-rata return dan risiko. Dari 16 sampel Reksa Dana saham diperoleh hasil bahwa keuntungan dan risiko Reksa Dana saham tidak ada yang lebih baik dari return pasar (LQ-45) dan tidak ada pengaruh positif antara rata-rata return dan risiko. Hasil penelitian dari Saraswati (2006) yang menyebutkan bahwa keuntungan Reksa Dana saham tidak ada yang lebih baik dari return pasar akan dapat dibuktikan dengan hasil penelitian ini.

Investasi dalam Reksa Dana saham memungkinkan investor memperoleh return yang tinggi sehingga keuntungan investor akan maksimal. Namun, Reksa Dana saham memiliki berbagai tingkat risiko mulai dari tingkat rendah sampai yang tinggi, sesuai dengan konsep "Low Risk Low Return dan High Risk High Return" setiap risiko tertentu akan memperoleh return tertentu. Pembentukan portofolio saham yang selalu berubah-ubah setiap saat, serta kebijakan alokasi aset yang tidak menentu akan sangat mempengaruhi hasil pengukuran kinerja Reksa Dana saham karena return yang dihasilkan juga terus berubah. Oleh karena itu, diperlukan sebuah pengetahuan untuk mengukur investasi yang dipilih dapat memberikan return sebanding dengan tingkat risiko yang diterima. Menyadari akan hal itu penulis tertarik untuk melakukan penelitian yang berjudul "Analisis
Pengukuran Kinerja Reksa Dana Saham dengan Metode Risk-Adjusted Return di Bursa Efek Indonesia Periode 2011-2013"

\section{METODE PENELITIAN}

\section{Jenis Penelitian}

Dalam penelitian ini penulis menggunakan pendekatan deskriptif kuantitatif. Penelitian deskriptif berupaya untuk memperoleh deskripsi yang lengkap dan akurat dari sebuah situasi (Kuncoro, 2007).

\section{Waktu dan Tempat Penelitian}

Penelitian ini dilakukan pada perusahaan Reksa Dana Saham yang terdaftar diBursa Efek Indonesia periode 2011-2013.Pengambilan data menggunakan internet pada situs www.kontan.co.id untuk data NAB mingguan Reksa Dana saham, www.finance.yahoo.com untuk data IHSG mingguan dan www.bi.go.id untuk data BI rate. Waktu penelitian dilakukan pada bulan September 2014 sampai selesai.

\section{Subjek Penelitian}

Subjek penelitian ini adalah Reksa Dana saham yang terdaftar di Bursa Efek Indonesia dan beroperasi pada tanggal 7 Januari 2011 sampai dengan 27 Desember 2014 kriteria sebagai berikut: 1) Sampel harus memiliki tanggal aktif sebelum periode penelitian, yaitu Januari 2011. 2) Sampel yang dipilih harus aktif beroperasi 
selama periode penelitian yaitu Januari 2011 hinggaDesember 2013. 3) Sampel masih aktif mengelola dana dalam bentuk Reksa Dana saham.

\section{Prosedur}

Penelitian diawali dengan penentuan populasi sebanyak 150 Reksa Dana saham. Pengambilan sampel menggunakan teknik purposive sampling dan diperoleh sampel sebanyak 52 Reksa Dana saham. Tahap selanjutnya adalah menghitung besarnya masing-masing variabel penelitian. Variabel pertama yaitu Return Reksa Dana saham, diperoleh dari selisih NAB pada periode pengamatan dan NAB pada periode sebelum pengamatan dibagi dengan NAB pada periode sebelum pengamatan. Variabel kedua Return pasar yang digunakan sebagai benchmark yaitu IHSG, Rumus yang digunakan sama seperti menghitung return Reksa Dana saham, hanya saja NAB per unit penyertaan diganti dengan IHSG. Variabel ketiga keuntungan investasi bebas risiko, diukur menggunakan BI rate. Selanjutnya ketiga variabel tersebut digunakan untuk mencari kinerja Reksa Dana saham dengan metode Sharpe, Treynor, dan Jensen, $M^{2}$ dan Information Ratio serta melihat perbandingan kinerja Reksa Dana saham dengan kinerja benchmark.

\section{Data dan Teknik Pengumpulan}

Data yang digunakan pada penelitian ini adalah data sekunder dimana metode pengumpulan datanya menggunakan metode dokumentasi dari berbagai literatur dan situs internet (www.bi.go.id, www.kontan.co.iddan

www.finance.yahoo.com). Data bersifat runtut waktu/time series, beberapa hal yang diperlukan dalam penelitian ini adalah : 1) NAB mingguan Reksa Dana saham $\left(N A B_{t}\right)$ periode Januari 2011Desember 2013. 2) Data BI rate $\left(R_{f}\right)$ periode Januari 2011-Desember 2013. 3) Data mingguan IHSG periode Januari 2011-Desember 2013.

\section{Teknik Analisis Data}

Teknik analisis data yang digunakan dalam penelitian ini deskriptif kuantitatif. Data diolah sesuai dengan definisi operasional variabel menggunakan bantuan program Microsoft Excel dengan langkah-langkah penghitungan sebagai berikut :

1. Mengumpulkan data NAB mingguan masing-masing Reksa Dana saham yang dijadikan sampel selama periode pengukuran serta data pergerakan IHSG dan BI rate selama periode pengukuran.

2. Menghitung return rata-rata masingmasing Reksa Dana saham dan return rata-rata benchmark yaitu IHSG. 
3. Menghitung risk free dengan menggunakan BI rate. Rumus yang digunakan adalah sebagai berikut:

$R_{R F}=\frac{\sum B I \text { rate }}{n}$

Di mana:

$\overline{R F}=$ Rata-rata investasi bebas risiko

$\sum$ BI rate $=$ Jumlah $\mathrm{BI}$ rate pada periode tertentu

$n=$ Jumlah periode perhitungan

4. Menghitung risiko, terdapat dua risiko yang dijadikan acuan pada penelitian ini, yaitu :

a. standar deviasi $(\sigma)$

Standar deviasi dihitung menggunakan rumus sebagai berikut :

$$
\begin{aligned}
& \sigma=\sqrt{\frac{\sum(X-\mu)^{2}}{n-1}} \\
& \mu=\frac{\sum X}{n} \\
& \quad \text { Di mana: } \\
& \sigma=\text { Standar deviasi } \\
& X=\text { Nilai data yang berada dalam } \\
& \text { sampel } \\
& \mu=\text { Rata-rata hitung } \\
& n=\text { Jumlah data }
\end{aligned}
$$

b. $\operatorname{Beta}(\beta)$.

Beta dapat dirumuskan sebagai berikut:

$$
\begin{aligned}
\beta_{p}= & \frac{\sigma_{i j}}{\sigma_{m^{2}}} \\
& \text { Di mana: } \\
& \beta_{p}=\text { Beta portofolio } \\
& \sigma_{i j}=\text { Kovarians }
\end{aligned}
$$
antara

return pasar dan return portofolio $\sigma_{m^{2}}=$ Varians pasar

5. Melakukan analisis penghitungan menggunakan Risk-Adjusted Return dengan metode Sharpe.
Rumus yang digunakan dengan metode Sharpe adalah sebagai berikut :

$$
\begin{aligned}
S_{R D}= & \frac{\bar{R}_{p}-\bar{R}_{f}}{\sigma_{p}} \\
& \text { Dimana : } \\
& S_{R D}=\text { Nilai Sharpe } \\
& \bar{R}_{p}=\text { Rata-rata keuntungan }
\end{aligned}
$$

Reksa Dana

$\bar{R}_{f}=$ Rata-rata keuntungan investasi bebas risiko

$\sigma_{p}=$ Standar deviasi

6. Melakukan analisis penghitungan menggunakan Risk-Adjusted Return dengan metode Treynor.

Perhitungan kinerja Reksa Dana dengan menggunakan metode Treynor, menggunakan risk premium dan $\operatorname{beta}(\beta)$ yang merupakan risiko fluktuatif. Rumus yang digunakan adalah sebagai berikut :

$T_{R D}=\frac{\bar{R}_{p}-\bar{R}_{f}}{\beta_{p}}$

Dimana :

$T_{R D}=$ Nilai Treynor

$\bar{R}_{p}=$ Rata-rata return Reksa Dana subperiode $\mathrm{t}$ (Mingguan)

$\bar{R}_{f}=$ Rata-rata return investasi bebas risiko periode $t$

$\beta_{p}=$ Beta persamaan garis regresi linear berganda

7. Melakukan analisis penghitungan menggunakan Risk-Adjusted Return dengan metode Jensen.

$$
\text { Adapun Rumus yang }
$$
dugunakan untuk menghitung menggunakan metode Jensen adalah sebagai berikut :

$$
\alpha=\left(\bar{R}_{p}-\bar{R}_{f}\right)-\beta_{p}\left(\bar{R}_{m}-\bar{R}_{f}\right)
$$

Dimana :

$$
\alpha=\text { Nilai perpotongan Jensen }
$$


Reksa Dana

$\bar{R}_{p}=$ Rata-rata keuntungan

$\bar{R}_{f}=$ Rata-rata keuntungan investasi bebas risiko

$\bar{R}_{m}=$ Rata-rata Keuntungan Pasar (IHSG)

8. Melakukan Analisis penghitungan menggunakan Risk-Adjusted Return dengan metode $M$-square.

Metode M-square merupakan perluasan dari metode Sharpe. Diperoleh dari menghitung Sharpe yang kemudian dikalikan dengan standar deviasi pasar dan ditambah dengan suku bunga bebas risiko (Risk Free) yang kemudian dikurangi dengan return pasar.Rumus yang digunakan adalah sebagai berikut :

$M^{2}=\left(\left(\frac{\bar{R}_{p}-\bar{R}_{f}}{\sigma_{p}} \mathrm{x} \sigma_{m}\right)+\bar{R}_{f}\right)-\bar{R}_{m}$ Dimana :

$M^{2}=M$-Square

$\bar{R}_{p}=$ Return rata-rata Reksa Dana

$\bar{R}_{f}=$ Return rata-rata investasi bebas risiko

Dana

$\sigma_{p}=$ Standar deviasi Reksa

$\sigma_{m}=$ Standar deviasi pasar

$\bar{R}_{m}=$ Return rata-rata Pasar

9. Melakukan analisis menggunakan Risk-Adjusted Return dengan metode Information Ratio.

IR diperoleh dari nilai Jensen, kemudian dibagi dengan risiko unik, yaitu selisih antara risiko total dan risiko sistematis. Rumus yang digunakan untuk IR/Information Ratio adalah sebagai berikut :
$\mathrm{IR}=\frac{\alpha}{\sigma_{e p}}$

Dimana :

$I R=$ Information Ratio

$\alpha=$ Nilai Jensen Alpha

$\sigma_{\text {ep }}=$ Risiko unik portofolio

10. Membandingkan hasil kinerja masing-masing Reksa Dana saham dengan kinerja benchmark (IHSG) agar dapat diketahui Reksa Dana mana saja yang mampu outperform ataupun underperform.

\section{HASILPENELITIAN}

DAN

\section{PEMBAHASAN}

Kinerja Reksa Dana Saham dengan Metode Sharpe

Kinerja Reksa Dana Saham pada tahun 2011 Menggunakan Metode Sharpe

Tabel 1. Hasil kinerja Reksa Dana saham pada tahun 2011 dengan metode Sharpe

\begin{tabular}{|l|l|}
\hline Kinerja Positif & Kinerja Negatif \\
\hline $\begin{array}{l}\text { 20 Reksa Dana } \\
\text { saham }\end{array}$ & $\begin{array}{l}\text { 32 Reksa Dana } \\
\text { saham }\end{array}$ \\
\hline
\end{tabular}

Berdasarkan hasil perhitungan kinerja Reksa Dana saham pada tahun 2011 menggunakan metode Sharpe, 20 Reksa Dana saham menunjukkan kinerja yang positif dan 32 Reksa Dana saham menunjukkan kinerja negatif. Hal ini menunjukkan bahwa 20 Reksa Dana saham berdasarkan metode Sharpe layak dijadikan sebagai tempat investasi. Reksa Dana saham dengan 
hasil positif menunjukkan bahwa return yang dihasilkan melebihi return investasi bebas risiko. Semakin besar hasil yang diperoleh maka semakin baik pula kinerja suatu Reksa Dana saham karena memberikan return yang tinggi atas risiko individual yang ditanggungnya. Berikut 10 Reksa Dana saham dengan kinerja terbaik berdasarkan Risk-Adjusted Returndengan metode Sharpe pada tahun 2011.

Tabel 2. Reksa Dana saham dengan kinerja terbaik pada tahun 2011 dengan metode Sharpe

\begin{tabular}{|l|l|l|}
\hline & Nama Reksa Dana saham & $\begin{array}{l}\text { Kinerja } \\
\text { Sharpe }\end{array}$ \\
\hline 1 & Makinta Mantap & 0,11080 \\
2 & Makinta Growth Fund & 0,04375 \\
3 & Panin Dana Maksima & 0,04323 \\
4 & Lautandhana Equity & \\
& Progressive & 0,03547 \\
5 & Millenium Equity & 0,03475 \\
6 & Panin Dana Prima & 0,02923 \\
7 & Schroder Dana Prestasi & 0,02837 \\
8 & First State Indoequity Peka & \\
& Fund & 0,02703 \\
9 & First State Indoequity & 0,02566 \\
& Value Select Fund & \\
10 & Schroder Dana Istimewa & 0,02151 \\
\hline
\end{tabular}

Reksa Dana saham yang memiliki kinerja paling tinggi adalah Reksa Dana saham Makinta Mantap dari Manajer Investasi PT Emco Asset Management dengan nilai Sharpe sebesar 0,11080.

1. Kinerja Reksa Dana Saham pada tahun 2012 Menggunakan Metode Sharpe
Tabel 3. Hasil kinerja Reksa Dana saham pada tahun 2012 dengan metode Sharpe

\begin{tabular}{|c|c|}
\hline Kinerja Positif & Kinerja Negatif \\
\hline $\begin{array}{l}42 \text { Reksa Dana } \\
\text { saham }\end{array}$ & 10 Reksa Dana saham \\
\hline
\end{tabular}

Berdasarkan hasil perhitungan kinerja Reksa Dana saham pada tahun 2012 menggunakan metode Sharpe, 42 Reksa Dana saham menunjukkan kinerja yang positif dan 10 Reksa Dana saham menunjukkan kinerja negatif. Hal ini menunjukkan bahwa 42 Reksa Dana saham berdasarkan metode Sharpe layak dijadikan sebagai tempat investasi. Reksa Dana saham dengan hasil positif menunjukkan bahwa return yang dihasilkan melebihi return investasi bebas risiko. Semakin besar hasil yang diperoleh maka semakin baik pula kinerja suatu Reksa Dana saham karena memberikan return yang tinggi atas risiko individual yang ditanggungnya. Berikut 10 Reksa Dana saham dengan kinerja terbaik berdasarkan RiskAdjusted Return dengan metode Sharpe pada tahun 2012.

Tabel 4. Reksa Dana saham terbaik dengan metode Sharpe pada tahun 2012

\begin{tabular}{|l|l|c|}
\hline & Nama Reksa Dana & $\begin{array}{c}\text { Kinerja } \\
\text { Sharpe }\end{array}$ \\
\hline 1 & $\begin{array}{l}\text { MNC Dana Ekuitas } \\
\text { Syailendra Equity Opportunity } \\
\text { Fund }\end{array}$ & 0,26546 \\
0,23001
\end{tabular}




\begin{tabular}{|l|l|l|}
3 & BNP Paribas Solaris & 0,18605 \\
4 & OSK Nusantara Alpha Sector & \\
& Rotation & 0,18078 \\
5 & BNP Paribas Pesona & 0,14482 \\
6 & Amanah & 0,14221 \\
7 & Cipta Syariah Equity & 0,12759 \\
8 & Dana Ekuitas Prima & \\
& BNP Paribas Infrastruktur & 0,12129 \\
9 & Plus & Danareksa Mawar Fokus 10 \\
10 & $\begin{array}{l}\text { Manulife Syariah Sektoral } \\
\text { Amanah }\end{array}$ & 0,11024 \\
& \multicolumn{2}{|l}{} \\
\hline
\end{tabular}

Reksa Dana saham yang memiliki kinerja paling tinggi adalah Reksa Dana saham MNC Dana Ekuitas dari Manajer Investasi PT MNC Asset Management dengan nilai Sharpe sebesar 0,26545 .

2. Kinerja Reksa Dana Saham pada tahun 2013 Menggunakan Metode Sharpe

Tabel 5. Hasil kinerja Reksa Dana saham pada tahun 2013 dengan metode Sharpe

\begin{tabular}{|l|l|}
\hline Kinerja Positif & Kinerja Negatif \\
\hline 6 Reksa Dana saham & $\begin{array}{l}46 \text { Reksa Dana } \\
\text { saham }\end{array}$ \\
\hline
\end{tabular}

Berdasarkan hasil perhitungan kinerja Reksa Dana saham pada tahun 2013 menggunakan metode Sharpe, 6 Reksa Dana saham menunjukkan kinerja yang positif dan 46 Reksa Dana saham menunjukkan kinerja negatif. Hal ini menunjukkan bahwa hanya 6 Reksa Dana saham berdasarkan metode Sharpe yang layak dijadikan sebagai tempat investasi. Reksa Dana saham dengan hasil positif menunjukkan bahwa return yang dihasilkan melebihi return investasi bebas risiko. Semakin besar hasil yang diperoleh maka semakin baik pula kinerja suatu Reksa Dana saham karena memberikan return yang tinggi atas risiko individual yang ditanggungnya. Berikut 10 Reksa Dana saham dengan kinerja terbaik berdasarkan Risk-Adjusted Return dengan metode Sharpe pada tahun 2013.

Tabel 6. Reksa Dana saham terbaik dengan metode Sharpe pada tahun 2013

\begin{tabular}{|l|l|r|}
\hline & Nama Reksa Dana saham & $\begin{array}{c}\text { Kinerja } \\
\text { Sharpe }\end{array}$ \\
\hline 1 & Millenium Equity & 0,31465 \\
2 & Grow 2 Prosper & 0,09458 \\
3 & Pratama Equity & 0,08845 \\
4 & Pratama Saham & 0,05944 \\
5 & Si Dana Saham Optimal & 0,00792 \\
6 & OSK Nusantara Alpha & \\
7 & Sector Rotation & 0,00398 \\
8 & Si Dana Saham Panin Dana Prima & $-0,00377$ \\
9 & Schroder Dana Prestasi & $-0,00867$ \\
10 & Schroder Indo Equity Fund & $-0,02092$ \\
& \multicolumn{2}{|l}{0,02235} \\
\hline
\end{tabular}

Reksa Dana saham yang memiliki kinerja paling tinggi adalah Reksa Dana saham Millenium Equity dari Manajer Investasi PT Millenium Danatama Indonesia dengan nilai Sharpe sebesar 0,31465 .

Kinerja Reksa Dana Saham denganMetode Treynor

1. Kinerja Reksa Dana Saham pada tahun 2011 dengan Metode Treynor 
Tabel 7. Hasil kinerja Reksa Dana saham pada tahun 2011 dengan metode Treynor

\begin{tabular}{|c|c|c|}
\hline Proxy & Kinerja Positif & \multicolumn{2}{|c|}{ Kinerja Negatif } \\
\hline IHSG & $\begin{array}{l}20 \text { Reksa Dana } \\
\text { saham }\end{array}$ & $\begin{array}{l}\text { 32 Reksa Dana } \\
\text { saham }\end{array}$ \\
\hline
\end{tabular}

Berdasarkan hasil perhitungan

kinerja Reksa Dana saham pada tahun 2011 menggunakan metode Treynor, 20

Reksa Dana saham menunjukkan kinerja yang positif dan 32 Reksa Dana saham menunjukkan kinerja negatif. Hal ini menunjukkan bahwa terdapat 20 Reksa Dana saham berdasarkan metode Treynor layak dijadikan sebagai tempat investasi. Reksa Dana saham dengan hasil positif menunjukkan bahwa return yang dihasilkan melebihi return investasi bebas risiko. Semakin besar hasil yang diperoleh maka semakin baik pula kinerja suatu Reksa Dana saham karena memberikan return yang tinggi atas risiko sistematis yang ditanggungnya. Berikut 10 Reksa Dana saham dengan kinerja terbaik berdasarkan Risk-Adjusted Return dengan metode Treynor pada tahun 2011.

Tabel 8. Reksa Dana saham terbaik dengan metode Treynor pada tahun 2011

\begin{tabular}{|l|l|l|}
\hline & \multicolumn{1}{|c|}{ Nama Reksa Dana } & $\begin{array}{l}\text { Kinerja } \\
\text { Treynor }\end{array}$ \\
\hline 1 & Makinta Mantap & 0,00327 \\
2 & Makinta Growth Fund & 0,00129
\end{tabular}

\begin{tabular}{|l|l|l|}
3 & Panin Dana Maksima & 0,00128 \\
4 & Lautandhana Equity & 0,00105 \\
& Progressive & \\
5 & Millenium Equity & 0,00103 \\
6 & Panin Dana Prima & 0,00086 \\
7 & Schroder Dana Prestasi & 0,00084 \\
8 & First State Indoequity Peka & 0,00080 \\
& Fund & \\
9 & First State Indoequity Value & 0,00076 \\
& Select Fund & \\
10 & Schroder Dana Istimewa & 0,00064 \\
\hline
\end{tabular}

Reksa Dana saham yang memiliki kinerja paling tinggi adalah Reksa Dana saham Makinta Mantap dari Manajer Investasi PT Emco Asset Management dengan nilai Treynor sebesar 0,00327 .

1. Kinerja Reksa Dana Saham pada tahun 2012 dengan Metode Treynor

Tabel 9. Hasil kinerja Reksa Dana saham pada tahun 2012 dengan metode Treynor

\begin{tabular}{|l|l|ll|}
\hline Proxy & \multicolumn{2}{|c|}{ Kinerja Positif } & \multicolumn{2}{|c|}{ Kinerja Negatif } \\
\hline IHSG & $\begin{array}{l}42 \text { Reksa Dana } \\
\text { saham }\end{array}$ & $\begin{array}{l}10 \text { Reksa Dana } \\
\text { saham }\end{array}$ \\
\hline
\end{tabular}

Berdasarkan hasil perhitungan kinerja Reksa Dana saham pada tahun 2012 menggunakan metode Treynor, 42 Reksa Dana saham menunjukkan kinerja yang positif dan hanya 10 Reksa Dana saham menunjukkan kinerja negatif. Hal ini menunjukkan bahwa terdapat 42 Reksa Dana saham berdasarkan metode Treynor layak dijadikan sebagai tempat investasi. Reksa Dana saham dengan hasil positif menunjukkan bahwa return yang dihasilkan melebihi return investasi 
bebas risiko. Semakin besar hasil yang diperoleh maka semakin baik pula kinerja suatu Reksa Dana saham karena memberikan return yang tinggi atas risiko sistematis yang ditanggungnya. Berikut 10 Reksa Dana saham dengan kinerja terbaik berdasarkan RiskAdjusted Return dengan metode Treynor pada tahun 2012.

Tabel 10. Reksa Dana saham terbaik dengan metode Treynor pada tahun 2012

\begin{tabular}{|l|l|l|}
\hline & \multicolumn{1}{|c|}{ Nama Reksa Dana } & $\begin{array}{l}\text { Kinerja } \\
\text { Treynor }\end{array}$ \\
\hline 1 & $\begin{array}{l}\text { MNC Dana Ekuitas } \\
\text { Syailendra Equity Opportunity } \\
\text { Fund }\end{array}$ & 0,00379 \\
3 & BNP Paribas Solaris & 0,00265 \\
4 & OSK Nusantara Alpha Sector & 0,00258 \\
& Rotation & \\
5 & BNP Paribas Pesona Amanah & 0,00207 \\
6 & Cipta Syariah Equity & 0,00203 \\
7 & Dana Ekuitas Prima & 0,00182 \\
8 & BNP Paribas Infrastruktur Plus & 0,00173 \\
9 & Danareksa Mawar Fokus 10 & 0,00157 \\
10 & Manulife Syariah Sektoral & 0,00150 \\
& Amanah & \\
\hline
\end{tabular}

Reksa Dana saham yang memiliki kinerja paling tinggi adalah Reksa Dana saham MNC Dana Ekuitas dari Manajer Investasi PT MNC Asset Management dengan nilai Treynor sebesar 0,00379 .

2. Kinerja Reksa Dana Saham pada tahun 2013 dengan Metode Treynor

Tabel 11. Hasil kinerja Reksa Dana saham pada tahun 2013 dengan metodeTreynor

\begin{tabular}{|c|c|c|}
\hline Proxy & Kinerja Positif & Kinerja Negatif \\
\hline $\mathrm{IH}$ & $\begin{array}{lrl}6 & \text { Reksa } & \text { Dana } \\
\text { saham }\end{array}$ & $\begin{array}{l}46 \text { Reksa D } \\
\text { saham }\end{array}$ \\
\hline
\end{tabular}

Berdasarkan hasil perhitungan kinerja Reksa Dana saham pada tahun 2013 menggunakan metode Treynor, 6 Reksa Dana saham menunjukkan kinerja yang positif dan 46 Reksa Dana saham menunjukkan kinerja negatif. Hal ini menunjukkan bahwa hanya terdapat 6 Reksa Dana saham berdasarkan metode Sharpe yang layak dijadikan sebagai tempat investasi. Reksa Dana saham dengan hasil positif menunjukkan bahwa return yang dihasilkan melebihi return investasi bebas risiko. Semakin besar hasil yang diperoleh maka semakin baik pula kinerja suatu Reksa Dana saham karena memberikan return yang tinggi atas risiko sistematis yang ditanggungnya. Berikut 10 Reksa Dana saham dengan kinerja terbaik berdasarkan RiskAdjusted Return dengan metode Treynor pada tahun 2013

Tabel 12. Reksa Dana saham terbaik dengan metode Treynor pada tahun 2013

\begin{tabular}{|l|l|r|}
\hline & \multicolumn{1}{|c|}{ Nama Reksa Dana } & $\begin{array}{c}\text { Kinerja } \\
\text { Treynor }\end{array}$ \\
\hline 1 & Millenium Equity & 0,00905 \\
2 & Grow 2 Prosper & 0,00269 \\
3 & Pratama Equity & 0,00252 \\
4 & Pratama Saham & 0,00169 \\
5 & Si Dana Saham Optimal & 0,00019 \\
6 & OSK Nusantara Alpha & 0,00008 \\
& Sector Rotation & \\
\end{tabular}




\begin{tabular}{|l|l|l|}
7 & Si Dana Saham & $-0,00015$ \\
8 & Panin Dana Prima & $-0,00028$ \\
9 & Schroder Dana Prestasi & $-0,00064$ \\
10 & $\begin{array}{l}\text { Schroder Indo Equity } \\
\text { Fund }\end{array}$ & \\
& & $-0,00068$ \\
\hline
\end{tabular}

Reksa Dana saham yang memiliki kinerja paling tinggi adalah Reksa Dana saham Millenium Equity dari Manajer Investasi PT MNC Asset Management dengan nilai Treynor sebesar 0,00905.

Kinerja Reksa Dana Saham dengan Metode Jensen

1. Kinerja Reksa Dana Saham pada tahun 2011 dengan Metode Jensen

Tabel 13. Hasil kinerja Reksa Dana saham pada tahun 2011 dengan metode Jensen

\begin{tabular}{|c|c|c|}
\hline Proxy & Kinerja Positif & \multicolumn{2}{|c|}{ Kinerja Negatif } \\
\hline IHSG & $\begin{array}{l}\text { 19 Reksa Dana } \\
\text { saham }\end{array}$ & $\begin{array}{l}\text { 33 Reksa Dana } \\
\text { saham }\end{array}$ \\
\hline
\end{tabular}

$$
\begin{array}{lr}
\text { Berdasarkan } & \text { hasil } \\
\text { perhitungan kinerja Reksa Dana } \\
\text { saham pada tahun } 2011 \text { menggunakan } \\
\text { metode Jensen, } 19 \text { Reksa Dana saham } \\
\text { menunjukkan kinerja yang positif dan }
\end{array}
$$
33 Reksa Dana saham menunjukkan kinerja negatif. Hal ini menunjukkan bahwa terdapat 19 Reksa Dana saham berdasarkan metode Jensen yang layak dijadikan sebagai tempat investasi. Kinerja Reksa Dana saham yang positif menunjukkan actual return yang lebih tinggi daripada return yang diharapkan, sedangkan kinerja Reksa Dana saham yang negatif menunjukkan actual return yang lebih rendah daripada return yang diharapkan. Semakin besar hasil yang diperoleh maka semakin baik pula kinerja suatu Reksa Dana saham karena memberikan actual return yang lebih tinggi daripada return yang diharapkan. Berikut 10 Reksa Dana saham dengan kinerja terbaik berdasarkan Risk-Adjusted Return

\begin{tabular}{|c|c|c|}
\hline & Nama Reksa Dana saham & $\begin{array}{c}\text { Kinerja } \\
\text { Jensen }\end{array}$ \\
\hline 1 & Makinta Mantap & 0,00350 \\
\hline 2 & Panin Dana Maksima & 0,00126 \\
\hline 3 & Makinta Growth Fund & 0,00109 \\
\hline 4 & Lautandhana Equity & \\
\hline 5 & $\begin{array}{l}\text { Progressive } \\
\text { Millenium Equity }\end{array}$ & $\begin{array}{l}0,00106 \\
0,00091\end{array}$ \\
\hline 6 & Panin Dana Prima & 0,00077 \\
\hline 7 & Schroder Dana Prestasi & 0,00072 \\
\hline 8 & First State Indoequity Peka & \\
\hline 9 & $\begin{array}{l}\text { Fund } \\
\text { First State Indoequity Value } \\
\text { Select Fund }\end{array}$ & $\begin{array}{l}0,00069 \\
0,00066\end{array}$ \\
\hline 10 & Schroder 90 plus equity fund & 0,00062 \\
\hline
\end{tabular}
dengan metode Jensen pada tahun

Tabel 14. Reksa Dana saham terbaik dengan metode Jensen pada tahun 2011

memiliki kinerja paling tinggi adalah Reksa Dana saham Makinta Mantap dari Manajer Investasi PT EMCO Asset Management dengan nilai Jensen sebesar 0,00350 .

2. Kinerja Reksa Dana Saham pada tahun 2012 dengan Metode Jensen 
Tabel 15. Hasil kinerja Reksa Dana saham pada tahun 2012 dengan metode Jensen

\begin{tabular}{|c|c|cc|}
\hline Proxy & Kinerja Positif & \multicolumn{2}{|c|}{ Kinerja Negatif } \\
\hline IHSG & $\begin{array}{l}\text { 12 Reksa Dana } \\
\text { saham }\end{array}$ & $\begin{array}{l}40 \\
\text { saham } \\
\text { sahsa }\end{array}$ \\
\hline
\end{tabular}

Berdasarkan

hasil

perhitungan kinerja Reksa Dana saham pada tahun 2012 menggunakan metode Jensen, 12 Reksa Dana saham menunjukkan kinerja yang positif dan 40 Reksa Dana saham menunjukkan kinerja negatif. Hal ini menunjukkan bahwa terdapat 12 Reksa Dana saham berdasarkan metode Jensen yang layak dijadikan sebagai tempat investasi. Kinerja Reksa Dana saham yang positif menunjukkan actual return yang lebih tinggi daripada return yang diharapkan, sedangkan kinerja Reksa Dana saham yang negatif menunjukkan actual return yang lebih rendah daripada return yang diharapkan. Semakin besar hasil yang diperoleh maka semakin baik pula kinerja suatu Reksa Dana saham karena memberikan actual return yang lebih tinggi daripada return yang diharapkan. Berikut 10 Reksa Dana saham dengan kinerja terbaik berdasarkan Risk-Adjusted Return dengan metode Jensen pada tahun 2012.
Tabel 16. Reksa Dana saham terbaik dengan metode Jensen pada tahun 2012

\begin{tabular}{|l|l|c|}
\hline & \multicolumn{1}{|c|}{ Nama Reksa Dana saham } & $\begin{array}{c}\text { Kinerja } \\
\text { Jensen }\end{array}$ \\
\hline 1 & $\begin{array}{l}\text { MNC Dana Ekuitas } \\
2\end{array}$ & 0,00268 \\
& $\begin{array}{l}\text { Syailendra Equity Opportunity } \\
\text { Fund }\end{array}$ & 0,00217 \\
4 & BNP Paribas Solaris & 0,00142 \\
& OSK Nusantara Alpha Sector & \\
5 & Rotation & 0,00135 \\
6 & BNP Paribas Pesona Amanah & 0,00078 \\
7 & Cipta Syariah Equity & 0,00072 \\
8 & Dana Ekuitas Prima & 0,00051 \\
9 & BNP Paribas Infrastruktur Plus & 0,00044 \\
10 & Danareksa Mawar Fokus 10 & 0,00024 \\
& Manulife Syariah Sektoral & \\
Amanah & 0,00018 \\
\hline
\end{tabular}

Reksa Dana saham yang memiliki kinerja paling tinggi adalah Reksa Dana saham MNC Dana Ekuitas dari Manajer Investasi PT MNC Asset Management dengan nilai Jensen sebesar 0,00268 .

3. Kinerja Reksa Dana Saham pada tahun 2013 dengan Metode Jensen $\mid$

Tabel 17. Hasil kinerja Reksa Dana saham pada tahun 2013 dengan metode Jensen

\begin{tabular}{|l|ll|l|}
\hline Proxy & \multicolumn{2}{|c|}{ Kinerja Positif } & \multicolumn{2}{c|}{ Kinerja Negatif } \\
\hline IHSG & $\begin{array}{l}19 \text { Reksa Dana } \\
\text { saham }\end{array}$ & $\begin{array}{l}\text { 33 Reksa Dana } \\
\text { saham }\end{array}$ \\
\hline
\end{tabular}

Berdasarkan hasil perhitungan kinerja Reksa Dana saham pada tahun 2013 menggunakan metode Jensen, 19 Reksa Dana saham menunjukkan kinerja yang positif dan 33 Reksa Dana saham menunjukkan kinerja negatif. Hal ini menunjukkan 
bahwa terdapat 19 Reksa Dana saham berdasarkan metode Jensen yang layak dijadikan sebagai tempat investasi. Kinerja Reksa Dana saham yang positif menunjukkan actual return yang lebih tinggi daripada return yang diharapkan, sedangkan kinerja Reksa Dana saham yang negatif menunjukkan actual return yang lebih rendah daripada return yang diharapkan. Semakin besar hasil yang diperoleh maka semakin baik pula kinerja suatu Reksa Dana saham karena memberikan actual return yang lebih tinggi daripada return yang diharapkan. Berikut 10 Reksa Dana saham dengan kinerja terbaik berdasarkan Risk-Adjusted Return dengan metode Jensen pada tahun 2013

Tabel 18.Reksa Dana saham terbaik dengan metode Jensen pada tahun 2013

\begin{tabular}{|c|l|c|}
\hline NO & Nama Reksa Dana saham & $\begin{array}{c}\text { Kinerja } \\
\text { Jensen }\end{array}$ \\
\hline 1 & Millenium Equity & 0,00975 \\
2 & Pratama Equity & 0,00493 \\
3 & Pratama Saham & 0,00383 \\
4 & Grow 2 Prosper & 0,00358 \\
5 & Si Dana Saham Optimal & 0,00166 \\
6 & OSK Nusantara Alpha & 0,00147 \\
& Sector Rotation & \\
7 & Panin Dana Prima & 0,00128 \\
8 & Si Dana Saham & 0,00123 \\
9 & Schroder Indo Equity Fund & 0,00073 \\
10 & Schroder Dana Prestasi & 0,00072 \\
\hline
\end{tabular}

Reksa Dana saham yang memiliki kinerja paling tinggi adalah
Reksa Dana saham Millenium Equity dari Manajer Investasi PT Millenium Danatama Indonesia dengan nilai Jensen sebesar 0,00975 .

Kinerja Reksa Dana Saham dengan Metode $M^{2}$

1. Kinerja Reksa Dana Saham pada tahun 2011 dengan Metode $M^{2}$

Tabel 19. Hasil kinerja Reksa Dana saham pada tahun 2011 dengan metode $M^{2}$

\begin{tabular}{|c|c|c|}
\hline Proxy & Kinerja Positif & Kinerja Negatif \\
\hline $\mathrm{IHS}$ & $\begin{array}{l}19 \text { Reksa Dana } \\
\text { saham }\end{array}$ & $\begin{array}{ll}33 \text { Reksa Dana } \\
\text { saham }\end{array}$ \\
\hline
\end{tabular}

Berdasarkan

hasil

perhitungan kinerja Reksa Dana saham pada tahun 2011 menggunakan metode $M^{2}$, 19 Reksa Dana saham menunjukkan kinerja yang positif dan 33 Reksa Dana saham menunjukkan kinerja negatif. Hal ini menunjukkan bahwa terdapat 19 Reksa Dana saham berdasarkan metode $M^{2}$ layak dijadikan sebagai tempat investasi. Kinerja Reksa Dana saham yang positif menunjukkan bahwa kinerja Reksa Dana saham lebih baik dari pada kinerja pasar (outperform). Sedangkan kinerja Reksa Dana saham yang negatif menunjukkan bahwa kinerja Reksa Dana berada dibawah kinerja pasar (underperform). Berikut 10 Reksa Dana saham dengan kinerja terbaik 
berdasarkan Risk-Adjusted Return

dengan metode $M^{2}$ pada tahun 2011.

Tabel 20. Reksa Dana saham terbaik dengan metode $M^{2}$ pada tahun 2011

\begin{tabular}{|l|l|c|}
\hline & Nama Reksa Dana saham & $\begin{array}{c}\text { Kinerja } \\
M^{2}\end{array}$ \\
\hline 1 & Makinta Mantap & 0,00310 \\
2 & Makinta Growth Fund & 0,00112 \\
32 & Panin Dana Maksima & 0,00111 \\
4 & Lautandhana Equity Progressive & 0,00088 \\
5 & Millenium Equity & 0,00086 \\
6 & Panin Dana Prima & 0,00069 \\
7 & Schroder Dana Prestasi & 0,00067 \\
8 & First State Indoequity Peka Fund & 0,00063 \\
9 & First State Indoequity Value & 0,00059 \\
& Select Fund & 0,00047 \\
10 & Schroder Dana Istimewa & 0 \\
\hline
\end{tabular}

Reksa Dana saham yang memiliki kinerja paling tinggi adalah Reksa Dana saham Makinta Mantap dari Manajer Investasi PT Emco Asset Management dengan nilai $M^{2}$ sebesar 0,00310 .

2. Kinerja Reksa Dana Saham pada tahun 2012 dengan Metode $M^{2}$

Tabel 21. Hasil kinerja Reksa Dana saham pada tahun 2012 dengan metode $M^{2}$

\begin{tabular}{|c|c|c|}
\hline Proxy & Kinerja Positif & Kinerja Negatif \\
\hline IHSG & $\begin{array}{l}12 \text { Reksa Dana } \\
\text { saham }\end{array}$ & $\begin{array}{l}40 \text { Reksa Dana } \\
\text { saham }\end{array}$ \\
\hline
\end{tabular}

Berdasarkan hasil perhitungan kinerja Reksa Dana saham pada tahun 2012 menggunakan metode $M^{2}, 12$ Reksa Dana saham menunjukkan kinerja yang positif dan 40 Reksa Dana saham menunjukkan kinerja negatif. Hal ini menunjukkan bahwa terdapat 12 Reksa Dana saham berdasarkan metode $M^{2}$ layak dijadikan sebagai tempat investasi. Kinerja Reksa Dana saham yang positif menunjukkan bahwa kinerja Reksa Dana saham lebih baik dari pada kinerja pasar (outperform). Sedangkan kinerja Reksa Dana saham yang negatif menunjukkan bahwa kinerja Reksa Dana berada dibawah kinerja pasar (underperform). Berikut 10 Reksa Dana saham dengan kinerja terbaik berdasarkan Risk-Adjusted Return dengan metode $M^{2}$ pada tahun 2012.

Tabel 22. Reksa Dana saham terbaik dengan metode $M^{2}$ pada tahun 2012

\begin{tabular}{|c|c|c|}
\hline NO & Nama Reksa Dana saham & $\begin{array}{c}\text { Kinerja } \\
M^{2}\end{array}$ \\
\hline 1 & NC Dana Ekuitas & 0,00245 \\
\hline 2 & $\begin{array}{l}\text { Syailendra } \\
\text { Opportunity Fund }\end{array}$ & \\
\hline 3 & BNP & 0,00132 \\
\hline 4 & $\begin{array}{l}\text { OSK Nusantara Alpha Sector } \\
\text { Rotation }\end{array}$ & 24 \\
\hline 5 & $\begin{array}{l}\text { BNP Paribas Pesona } \\
\text { Amanah }\end{array}$ & 0,00073 \\
\hline 6 & Cipta & 0,00 \\
\hline 7 & Dana $\mathrm{F}$ & 48 \\
\hline 8 & $\begin{array}{l}\text { BNP Paribas Infrastruktur } \\
\text { Plus }\end{array}$ & 0,00039 \\
\hline 9 & Danareksa Ma & 0,00023 \\
\hline 10 & $\begin{array}{l}\text { Manulife Syariah Sektoral } \\
\text { Amanah }\end{array}$ & 0,00016 \\
\hline
\end{tabular}


Reksa Dana saham yang memiliki kinerja paling tinggi adalah Reksa Dana saham MNC Dana Ekuitas dari

3. Kinerja Reksa Dana Saham pada tahun 2013 dengan Metode $M^{2}$

Tabel 23. Hasil kinerja Reksa Dana saham pada tahun 2013 dengan metode $M^{2}$

\begin{tabular}{|c|c|c|}
\hline Proxy & Kinerja Positif & Kinerja Negatif \\
\hline IHSC & $\begin{array}{l}23 \text { Reksa Dana } \\
\text { saham }\end{array}$ & $\begin{array}{l}29 \text { Reksa Dana } \\
\text { saham }\end{array}$ \\
\hline
\end{tabular}

Berdasarkan hasil perhitungan kinerja Reksa Dana saham pada tahun 2013 menggunakan metode $M^{2}, 23$ Reksa Dana saham menunjukkan kinerja yang positif dan 29 Reksa Dana saham menunjukkan kinerja negatif. Hal ini menunjukkan bahwa terdapat 23 Reksa Dana saham berdasarkan metode $M^{2}$ layak dijadikan sebagai tempat investasi. Kinerja Reksa Dana saham yang positif menunjukkan bahwa kinerja Reksa Dana saham lebih baik dari pada kinerja pasar (outperform). Sedangkan kinerja Reksa Dana saham yang negatif menunjukkan bahwa kinerja Reksa Dana berada dibawah kinerja pasar (underperform). Berikut 10 Reksa Dana Kinerja Reksa Dana saham dengan Metode Information Ratio
Manajer Investasi PT MNC Asset Mangement dengan nilai $M^{2}$ sebesar 0,00245 .

saham dengan kinerja terbaik berdasarkan Risk-Adjusted Return dengan metode $M^{2}$ pada tahun 2013.

Tabel 24. Reksa Dana saham terbaik dengan metode $M^{2}$ pada tahun 2013

\begin{tabular}{|c|c|c|}
\hline $\mathrm{NO}$ & $\begin{array}{l}\text { Nama Reksa } \\
\text { Dana saham }\end{array}$ & $\begin{array}{r}\text { Kinerja } \\
M^{2}\end{array}$ \\
\hline 1 & Millenium Equity & 0,01060 \\
\hline 2 & Grow 2 Prosper & 0,00425 \\
\hline 3 & Pratama Equity & 0,00400 \\
\hline 4 & $\begin{array}{l}\text { Pratama Saham } \\
\text { Si Dana Saham }\end{array}$ & 0,00317 \\
\hline 5 & Optimal & 0,00170 \\
\hline 6 & $\begin{array}{lr}\text { OSK } & \text { Nusantara } \\
\text { Alpha } & \text { Sector } \\
\text { Rotation } & \end{array}$ & 0,00160 \\
\hline 7 & $\begin{array}{l}\text { Si Dana Saham } \\
\text { Panin Dana }\end{array}$ & 0,00137 \\
\hline 8 & $\begin{array}{l}\text { Prima } \\
\text { Schroder Dana }\end{array}$ & 0,00120 \\
\hline 10 & $\begin{array}{l}\text { Prestasi } \\
\text { Cipta Syariah } \\
\text { Equity }\end{array}$ & 0,00087 \\
\hline
\end{tabular}

Reksa Dana saham yang memiliki kinerja paling tinggi adalah Reksa Dana saham Millenium Equity dari Manajer Investasi PT Millenium Danatama Indonesia dengan nilai $M^{2}$ sebesar 0,01060. 
1. Kinerja Reksa Dana Saham pada tahun 2011 dengan Metode Information Ratio

Tabel 25. Hasil kinerja Reksa Dana saham pada tahun 2011 dengan metode Information Ratio

\begin{tabular}{|c|cc|c|}
\hline Proxy & \multicolumn{2}{|c|}{ Kinerja Positif } & $\begin{array}{c}\text { Kinerja } \\
\text { Negatif }\end{array}$ \\
\hline IHSG & $\begin{array}{c}19 \text { Reksa Dana } \\
\text { saham }\end{array}$ & $\begin{array}{c}33 \\
\text { Dana saham }\end{array}$ \\
\hline
\end{tabular}

\section{Berdasarkan}

hasil

perhitungan kinerja Reksa Dana saham pada tahun 2011 menggunakan metode Information Ratio, 19 Reksa Dana saham menunjukkan kinerja yang positif dan 33 Reksa Dana saham menunjukkan kinerja negatif. Hal ini menunjukkan bahwa terdapat 19 Reksa Dana saham berdasarkan metode Information Ratio layak dijadikan sebagai tempat investasi. Kinerja Reksa Dana saham yang positif menunjukkan bahwa kinerja Reksa Dana saham lebih baik dari pada kinerja pasar (outperform). Sedangkan kinerja Reksa Dana saham yang negatif menunjukkan bahwa kinerja Reksa Dana berada dibawah kinerja pasar (underperform). Berikut 10 Reksa Dana saham dengan kinerja terbaik berdasarkan Risk-Adjusted Return dengan metode Information Ratio tahun 2011.
Tabel 26. Reksa Dana saham terbaik dengan metode Information Ratio pada tahun 2011

\begin{tabular}{|c|l|c|}
\hline $\mathrm{N}$ & Kama Reksa Dana saham & $\begin{array}{c}\text { Kinerja } \\
\text { Information } \\
\text { Ratio }\end{array}$ \\
\hline 1 & Makinta Mantap & 0,00320 \\
2 & Makinta Growth Fund & 0,00116 \\
3 & Panin Dana Maksima & 0,00114 \\
4 & Lautandhana Equity & 0,00091 \\
& Progressive & 0,00088 \\
5 & Millenium Equity & 0,00072 \\
6 & Panin Dana Prima & 0,00069 \\
7 & Schroder Dana Prestasi \\
8 & First State Indoequity Peka & 0,00065 \\
& Fund & 0,00061 \\
9 & First State Indoequity Value & \\
& Select Fund & 0,00048 \\
10 & Schroder Dana Istimewa & \\
\hline
\end{tabular}

Reksa Dana saham yang memiliki kinerja paling tinggi adalah Reksa Dana saham Makinta Mantap dari Manajer Investasi PT EMCO Asset Management dengan nilai Information Ratio sebesar 0,00320.

2. Kinerja Reksa Dana Saham pada tahun 2012 dengan Metode Information Ratio

Tabel 27. Hasil kinerja Reksa Dana saham pada tahun 2012 dengan metode Information Ratio

\begin{tabular}{|c|c|c|}
\hline Proxy & Kinerja Positif & \multicolumn{2}{|c|}{ Kinerja Negatif } \\
\hline IHSG & $\begin{array}{l}12 \text { Reksa Dana } \\
\text { saham }\end{array}$ & $\begin{array}{l}40 \text { Reksa Dana } \\
\text { saham }\end{array}$ \\
\hline
\end{tabular}

Berdasarkan hasil perhitungan kinerja Reksa Dana saham pada tahun 2012 menggunakan metode Information Ratio, 12 Reksa 
Dana saham menunjukkan kinerja yang positif dan 40 Reksa Dana saham menunjukkan kinerja negatif. Hal ini menunjukkan bahwa terdapat 12 Reksa Dana saham berdasarkan metode Information Ratio layak dijadikan sebagai tempat investasi.

Kinerja Reksa Dana saham yang positif menunjukkan bahwa kinerja Reksa Dana saham lebih baik dari pada kinerja pasar (outperform). Sedangkan kinerja Reksa Dana saham yang negatif menunjukkan bahwa kinerja Reksa Dana berada dibawah kinerja pasar (underperform). Berikut 10 Reksa Dana saham dengan kinerja terbaik berdasarkan Risk-Adjusted Return dengan metode Information Ratio tahun 2012.

Tabel 28. Reksa Dana saham terbaik $\begin{array}{lr}\text { dengan } & \text { metode } \\ \text { Information Ratio pada } \\ \text { tahun } 2012\end{array}$

\begin{tabular}{|c|c|c|}
\hline NO & Nama Reksa Dana saham & $\begin{array}{c}\text { Kinerja } \\
\text { Informati } \\
\text { on Ratio }\end{array}$ \\
\hline 1 & MNC Dana Ekuitas & 0,00248 \\
\hline 2 & $\begin{array}{ll}\text { Syailendra } & \text { Equity } \\
\text { Opportunity Fund } & \end{array}$ & 0,00197 \\
\hline 3 & BNP Paribas Solaris & 0,00133 \\
\hline 4 & $\begin{array}{l}\text { OSK Nusantara Alpha Sector } \\
\text { Rotation }\end{array}$ & 0,00126 \\
\hline 5 & $\begin{array}{l}\text { BNP Paribas Pesona } \\
\text { Amanah }\end{array}$ & 0,00074 \\
\hline 6 & Cipta Syariah Equity & 0,00070 \\
\hline 7 & Dana Ekuitas Prima & 0,00049 \\
\hline 8 & $\begin{array}{l}\text { BNP Paribas Infrastruktur } \\
\text { Plus }\end{array}$ & 0,00040 \\
\hline 9 & Danareksa Mawar Fokus 10 & 0,00024 \\
\hline 10 & $\begin{array}{l}\text { Manulife Syariah Sektoral } \\
\text { Amanah }\end{array}$ & 0,00016 \\
\hline
\end{tabular}

Reksa Dana saham yang memiliki kinerja paling tinggi adalah Reksa Dana saham MNC Dana Ekuitas dari Manajer Investasi PT MNC Asset Management dengan nilai Information Ratio sebesar 0,00248.

3. Kinerja Reksa Dana Saham pada tahun 2013 dengan Metode Information Ratio

Tabel 29. Hasil kinerja Reksa Dana saham pada tahun 2013 dengan metode Information Ratio

\begin{tabular}{|c|c|c|}
\hline Proxy & Kinerja Positif & Kinerja Negatif \\
\hline IHSG & $\begin{array}{l}19 \text { Reksa Dana } \\
\text { saham }\end{array}$ & $\begin{array}{l}\text { 33 Reksa Dana } \\
\text { saham }\end{array}$ \\
\hline
\end{tabular}

Berdasarkan hasil perhitungan kinerja Reksa Dana saham pada tahun 2013 menggunakan metode Information Ratio, 19 Reksa Dana saham menunjukkan kinerja yang positif dan 33 Reksa Dana saham menunjukkan kinerja negatif. Hal ini menunjukkan bahwa terdapat 12 Reksa Dana saham berdasarkan metode Information Ratio layak dijadikan sebagai tempat investasi. Kinerja Reksa Dana saham yang positif menunjukkan bahwa kinerja Reksa Dana saham lebih baik dari pada kinerja pasar (outperform). Sedangkan kinerja Reksa Dana saham yang negatif menunjukkan bahwa kinerja Reksa Dana berada dibawah 
kinerja pasar (underperform). Berikut 10

Reksa Dana saham dengan kinerja terbaik berdasarkan Risk-Adjusted Return dengan metode Information Ratio tahun 2013.

Tabel 30. Reksa Dana saham terbaik dengan metode Information Ratio pada tahun 2013

\begin{tabular}{|c|l|c|}
\hline NO & \multicolumn{1}{|c|}{ Nama Reksa Dana } & $\begin{array}{c}\text { Kinerja } \\
\text { Information } \\
\text { Ratio }\end{array}$ \\
\hline 1 & Millenium Equity & 0,01069 \\
2 & Grow 2 Prosper & 0,00414 \\
3 & Pratama Equity & 0,00396 \\
4 & Pratama Saham & 0,00309 \\
5 & Si Dana Saham Optimal & 0,00156 \\
6 & OSK Nusantara Alpha & 0,00144 \\
7 & Sector Rotation & 0,00121 \\
8 & Si Dana Saham Panin Dana Prima & 0,00106 \\
9 & Schroder Dana Prestasi & 0,00070 \\
10 & Schroder Indo Equity Fund & 0,00066 \\
\hline
\end{tabular}

Reksa Dana saham yang memiliki kinerja paling tinggi adalah Reksa Dana saham Millenium Equity dari Manajer Investasi PT Millenium Danatama Indonesia dengan nilai Information Ratio sebesar 0,01069.

Perbandingan Kinerja Reksa Dana

Saham dengan Kinerja Benchmark

1. Perbandingan Kinerja Reksa Dana Saham dengan Kinerja Benchmark pada tahun 2011

Suatu Reksa Dana dapat dijadikan tempat investasi yang menguntungkan apabila memiliki kinerja yang melebihi kinerja pasar (outperform), sedangkan sebuah Reksa Dana yang memiliki kinerja dibawah kinerja pasar (underperform) masih merupakan investasi yang perlu untuk diperhitungkan kembali karena return yang dihasilkan dibawah return pasar. Hasil perbandingan kinerja Reksa Dana saham dengan kinerja Benchmark pada tahun 2011 dapat dilihat pada tabel berikut :

Tabel 31. Hasil Perbandingan Kinerja Reksa Dana Saham dengan Kinerja Benchmark pada tahun 2011

\begin{tabular}{|l|l|l|}
\hline $\begin{array}{c}\text { Proxy } \\
\text { Benchmark }\end{array}$ & \multicolumn{1}{c|}{$\begin{array}{c}\text { Status } \\
\text { Outperform }\end{array}$} & $\begin{array}{c}\text { Status } \\
\text { Underperform }\end{array}$ \\
\hline IHSG & $\begin{array}{l}\text { 18 Reksa Dana } \\
\text { saham }\end{array}$ & $\begin{array}{l}\text { 34 Reksa Dana } \\
\text { saham }\end{array}$ \\
\hline
\end{tabular}

Berdasarkan hasil perbandingan diatas kinerja Reksa Dana saham pada tahun 2011 menunjukkan 18 Reksa Dana saham memiliki status outperform terhadap kinerja benchmark (IHSG) dan 34 Reksa Dana saham lainnya memiliki status underperform. Berikut 10 kinerja Reksa Dana saham terbaik pada tahun 2011.

Tabel 32. Kinerja Benchmark dan Reksa Dana saham terbaik pada tahun 2011

\begin{tabular}{|c|l|c|c|}
\hline NO & $\begin{array}{l}\text { Nama Reksa } \\
\text { Dana saham }\end{array}$ & Kinerja & Status \\
\hline 1 & $\begin{array}{l}\text { Makinta } \\
2\end{array}$ & 0,25139 & Outperform \\
Mantap & $\begin{array}{l}\text { Panin Dana } \\
\text { Maksima }\end{array}$ & 0,11612 & Outperform \\
Makinta Growth & 0,11367 & Outperform
\end{tabular}




\begin{tabular}{|c|c|c|c|}
\hline & Fund & & \\
\hline 4 & $\begin{array}{l}\text { Lautandhana } \\
\text { Equity } \\
\text { Progressive }\end{array}$ & 0,10148 & Outperform \\
\hline 5 & $\begin{array}{l}\text { Millenium } \\
\text { Equity }\end{array}$ & 0,10020 & Outperform \\
\hline 6 & $\begin{array}{l}\text { Panin Dana } \\
\text { Prima }\end{array}$ & 0,08991 & Outperform \\
\hline 7 & $\begin{array}{l}\text { Schroder Dana } \\
\text { Prestasi }\end{array}$ & 0,08858 & Outperform \\
\hline 8 & $\begin{array}{l}\text { First State } \\
\text { Indoequity Peka } \\
\text { Fund }\end{array}$ & 0,08631 & Outperform \\
\hline 9 & $\begin{array}{l}\text { First State } \\
\text { Indoequity Value } \\
\text { Select Fund }\end{array}$ & 0,08363 & Outperform \\
\hline 10 & $\begin{array}{l}\text { Schroder Dana } \\
\text { Istimewa } \\
\text { IHSG }\end{array}$ & $\begin{array}{l}0,07556 \\
0,05247\end{array}$ & Outperform \\
\hline
\end{tabular}

Berdasarkan pada tabel $32 \mathrm{di}$ atas Reksa Dana saham yang memiliki kinerja paling tinggi pada tahun 2011 adalah Makinta Mantap dari Manajer Investasi PT EMCO Asset Management dengan return $25.139 \%$.

2. Perbandingan Kinerja Reksa Dana Saham dengan Kinerja Benchmark pada tahun 2012

Tabel 33. Hasil Perbandingan Kinerja Reksa Dana Saham dengan Kinerja Benchmark pada tahun 2012

\begin{tabular}{|l|l|l|}
\hline $\begin{array}{c}\text { Proxy } \\
\text { Benchmark }\end{array}$ & \multicolumn{1}{|c|}{$\begin{array}{c}\text { Status } \\
\text { Outperform }\end{array}$} & \multicolumn{2}{c|}{$\begin{array}{c}\text { Status } \\
\text { Underperform }\end{array}$} \\
\hline IHSG & $\begin{array}{l}\text { 13 Reksa Dana } \\
\text { saham }\end{array}$ & $\begin{array}{l}39 \text { Reksa } \\
\text { Dana saham }\end{array}$ \\
\hline
\end{tabular}

$$
\text { Berdasarkan }
$$
hasil perbandingan diatas kinerja Reksa Dana saham pada tahun 2012 menunjukkan 13 Reksa Dana saham memiliki status outperform terhadap kinerja benchmark (IHSG) dan 39 Reksa

Dana saham lainnya memiliki status underperform. Berikut 10 kinerja Reksa

Dana saham terbaik pada tahun 2012.

Tabel 34. Kinerja Benchmark dan Reksa Dana saham terbaik pada tahun 2012

\begin{tabular}{|c|c|c|c|}
\hline $\mathrm{NO}$ & $\begin{array}{l}\text { Nama Reksa } \\
\text { Dana Saham }\end{array}$ & Kinerja & Status \\
\hline 1 & $\begin{array}{l}\text { MNC Dana } \\
\text { Ekuitas }\end{array}$ & 29087 & utperfor \\
\hline 2 & $\begin{array}{l}\text { Syailendra Equity } \\
\text { Opportunity } \\
\text { Fund }\end{array}$ & 0,25972 & Outperform \\
\hline 3 & $\begin{array}{l}\text { BNP Paribas } \\
\text { Solaris }\end{array}$ & 0,20315 & Outperform \\
\hline 4 & $\begin{array}{l}\text { usantara } \\
\text { iector }\end{array}$ & 0,18915 & Outperform \\
\hline 5 & $\begin{array}{l}\text { BNP } \\
\text { Peso }\end{array}$ & 0,16323 & Outperform \\
\hline 6 & $\begin{array}{l}\text { BNP Paribas } \\
\text { Infrastruktur } \\
\text { Plus }\end{array}$ & 0,14816 & Outperform \\
\hline 7 & $\begin{array}{l}\text { Dana Ekuitas } \\
\text { Prima }\end{array}$ & 0,14401 & Outperform \\
\hline 8 & $\begin{array}{l}\text { Cipta Syariah } \\
\text { Equity }\end{array}$ & 0,14236 & Outperform \\
\hline 9 & $\begin{array}{l}\text { Si Dana Saham } \\
\text { Syariah }\end{array}$ & 0,13400 & Outperform \\
\hline 10 & $\begin{array}{l}\text { Manulife } \\
\text { Syariah Sektoral } \\
\text { Amanah } \\
\text { IHSG }\end{array}$ & 0,13217 & Outperform \\
\hline
\end{tabular}

Berdasarkan pada tabel $32 \mathrm{di}$ atas Reksa Dana saham yang memiliki kinerja paling tinggi pada tahun 2012 adalah MNC Dana Ekuitas dari Manajer Investasi PT MNC Asset Management dengan return $29.087 \%$. 
3. Perbandingan Kinerja Reksa Dana Saham dengan Kinerja Benchmark pada tahun 2013

Tabel 35. Hasil Perbandingan Kinerja Reksa Dana Saham dengan Kinerja Benchmark pada tahun 2013

\begin{tabular}{|c|lc|c|}
\hline $\begin{array}{c}\text { Proxy } \\
\text { Benchmark }\end{array}$ & \multicolumn{2}{|c|}{$\begin{array}{c}\text { Status } \\
\text { Outperform }\end{array}$} & \multicolumn{2}{|c|}{$\begin{array}{c}\text { Status } \\
\text { Underperform }\end{array}$} \\
\hline IHSG & $\begin{array}{l}\text { I6 } \\
\text { Dana saham }\end{array}$ & $\begin{array}{l}\text { 36 Reksa Dana } \\
\text { saham }\end{array}$ \\
\hline
\end{tabular}

Berdasarkan hasil perbandingan diatas kinerja Reksa Dana saham pada tahun 2012 menunjukkan 16 Reksa Dana saham memiliki status outperform terhadap kinerja benchmark (IHSG) dan 36 Reksa Dana saham lainnya memiliki status underperform. Berikut 10 kinerja Reksa Dana saham terbaik pada tahun 2013.

Tabel 36. Kinerja Benchmark dan Reksa

Dana saham terbaik pada tahun 2013

\begin{tabular}{|c|c|c|c|}
\hline $\mathrm{NO}$ & $\begin{array}{c}\text { Nama } \\
\text { Reksa Dana } \\
\text { Saham }\end{array}$ & Kinerja & Status \\
\hline 1 & $\begin{array}{l}\text { Millenium } \\
\text { Equity }\end{array}$ & 0,58247 & Outperform \\
\hline 2 & $\begin{array}{ll}\text { Grow } & 2 \\
\text { Prosper } & \end{array}$ & 0,16772 & Outperform \\
\hline 3 & $\begin{array}{l}\text { Pratama } \\
\text { Equity }\end{array}$ & 0,15825 & Outperform \\
\hline 4 & $\begin{array}{l}\text { Pratama } \\
\text { Saham }\end{array}$ & 0,09637 & Outperform \\
\hline 5 & $\begin{array}{l}\text { Si Dana } \\
\text { Saham } \\
\text { Optimal }\end{array}$ & 0,03803 & Outperform \\
\hline 6 & $\begin{array}{l}\text { OSK } \\
\text { Nusantara } \\
\text { Alpha Sector } \\
\text { Rotation }\end{array}$ & 0,02849 & Outperform \\
\hline 7 & $\begin{array}{l}\text { Si Dana } \\
\text { Saham }\end{array}$ & 0,01998 & Outperform \\
\hline
\end{tabular}

\begin{tabular}{|c|c|c|c|}
\hline 8 & Panin Dana & $-0,00394$ & Outperform \\
\hline 9 & Lautandhana & $-0,00476$ & Outperform \\
\hline & Equity & & \\
\hline 10 & $\begin{array}{l}\text { Progressive } \\
\text { Schroder }\end{array}$ & -0.01149 & Outnerform \\
\hline & Dana & & \\
\hline & Prestasi & & \\
\hline & IHSG & $-0,04468$ & \\
\hline
\end{tabular}

Berdasarkan pada tabel 32 di atas terdapat 7 Reksa Dana saham yang memiliki kinerja positif dan 3 Reksa Dana saham memiliki kinerja negatif namun kesepuluh Reksa Dana tersebut memiliki status outperform terhadap kinerja benchmark. Reksa Dana saham yang memiliki kinerja paling tinggi pada tahun 2013 adalah Millenium Equity dari Manajer Investasi PT Millenium Danatama Indonesia dengan return $58.247 \%$ yang merupakan return paling tinggi diantara 2 tahun sebelumnya.

Reksa Dana Saham yang memiliki Kinerja Positif dan Outperform terhadap Kinerja Benchmark

Berdasarkan perhitungan dengan Risk-Adjusted Return yang digunakan tidak terdapat satupun Reksa Dana saham yang konsisten memiliki kinerja Positif selama tahun 2011, 2012 dan 2013 dengan 5 metode yang digunakan. Hanya terdapat satu Reksa Dana saham yang konsisten selama 3 tahun memiliki status outperform yaitu Reksa Dana saham Cipta Syariah Equity 
dari Manajer Investasi PT Cipta Dana Asset Management.

Berdasarkan perhitungan dengan metode Jensen, M-square dan Information Ratio, Reksa Dana saham Cipta Syariah Equity merupakan satu-satunya Reksa Dana yang memiliki kinerja positif selama tahun 2011, 2012 dan 2013. Sedangkan berdasarkan perhitungan dengan metode Sharpe dan Treynor Reksa Dana Cipta Syariah Equity memiliki kinerja negatif hanya pada tahun 2013 saja.

Tabel 37. Kinerja Reksa Dana saham Cipta Syariah Equity dengan metode Sharpe, Treynor, Jensen, $M^{2}$, Information Ratio

\begin{tabular}{|r|l|r|r|r|}
\hline \multirow{2}{*}{ No } & \multicolumn{1}{|c|}{$\begin{array}{c}\text { Risk- } \\
\text { Adjusted } \\
\text { Retrun }\end{array}$} & 2011 & 2012 & 2013 \\
\cline { 3 - 5 } & Sharpe & 0,01783 & 0,14221 & $-0,02329$ \\
2 & Treynor & 0,00053 & 0,00203 & $-0,00072$ \\
3 & Jensen & 0,00042 & 0,00072 & 0,00056 \\
4 & $M^{2}$ & 0,00036 & 0,00069 & 0,00084 \\
5 & Information & 0,00037 & 0,00070 & 0,00063 \\
& Ratio & & & \\
\hline
\end{tabular}

Berdasarkan Tabel 37 di atas dapat diketahui bahwa pada tahun 2013 Reksa Dana saham Cipta Syariah Equity berdasarkan metode Sharpe dan Treynor memiliki kinerja negatif. Hal ini menunjukkan bahwa pada tahun 2013 Reksa Dana Cipta Syariah Equity memiliki return yang belum mampu melebihi return investasi bebas risiko, sedangkan pada tahun 2011 dan 2012 Reksa Dana Cipta Syariah Equity memiliki return diatas return investasi bebas risiko. Namun, berdasarkan metode Jensen, $M^{2}$, dan Information Ratioyang merupakan metode yang menyesuaikan tingkat risiko individual dengan tingkat risiko pasar menjadi sama dengan nol Reksa Dana Cipta Syariah Equity selalu konsisten memiliki kinerja yang positif dari tahun 2011, 2012 dan 2013. Hal ini menunjukkan bahwa kinerja Reksa Dana saham Cipta Syariah Equity selama tahun 2011, 2012 dan 2013 selalu berada di atas pasar (outperform), meskipun pada tahun 2013 belum melebihi return investasi bebas risiko namun return yang dihasilkan masih berada diatas return pasar. Hal ini dapat dibuktikan dari perbandingan kinerja Reksa Dana Cipta Syariah Equity dengan kinerja benchmark sebagai berikut :

Tabel 38. Perbandingan Kinerja Reksa Dana saham Cipta Syariah Equity dengan Kinerja Benchmark

\begin{tabular}{|c|r|r|c|}
\hline Tahun & $\begin{array}{c}\text { Kinerja Cipta } \\
\text { Syariah } \\
\text { Equity }\end{array}$ & $\begin{array}{c}\text { Kinerja } \\
\text { benchmark }\end{array}$ & Status \\
\hline 2011 & 0,06764 & 0,05247 & Outperfom \\
2012 & 0,14236 & 0,11559 & Outperfom \\
2013 & $-0,01285$ & $-0,04468$ & Outperfom \\
\hline
\end{tabular}

Berdasarkan tabel 38 di atas dapat dilihat bahwa pada tahun 2013 Reksa Dana saham Cipta Syariah Equity memiliki return yang negatif namun masih berada di atas return pasar. Hasil diatas menunjukkan bahwa Cipta Syariah Equity 
merupakan Reksa Dana saham yang paling layak dijadikan tempat investasi bagi para investor karena return yang dihasilkan selama 3 tahun selalu konsisten diatas return pasar.

\section{KESIMPULAN DAN SARAN}

Kesimpulan

Berdasarkan analisis hasil penelitian dapat disimpulkan sebagai berikut :

4. Berdasarkan metode Sharpe pada tahun 2011, terdapat 20 Reksa Dana saham yang memiliki kinerja positif dan 32 Reksa Dana saham memiliki kinerja negatif. Pada tahun 2012, 42 Reksa saham memiliki kinerja positif dan 10 Reksa Dana saham yang memiliki kinerja negatif. Sedangkan pada tahun 2013, hanya terdapat 6 Reksa Dana saham yang memiliki kinerja positif, 46 Reksa Dana saham lainnya memiliki kinerja yang negatif.

5. Berdasarkan metode Treynor dengan proxy IHSG pada tahun 2011 terdapat 20 Reksa Dana saham dengan kinerja positif dan 32 Reksa Dana saham dengan kinerja negatif. Pada tahun 2012, terdapat 42 Reksa Dana saham yang memiliki kinerja positif, 10 Reksa Dana lainnya memiliki kinerja negatif. Sedangkan pada tahun 2013, hanya terdapat 6 Reksa Dana yang memiliki kinerja yang positif, 46 Reksa Dana lainnya memiliki kinerja negatif.

6. Berdasarkan metode Jensen pada tahun 2011, terdapat 19 Reksa Dana saham yang memiliki kinerja positif, 33 Reksa Dana saham lainnya memiliki kinerja yang negatif. Pada tahun 2012, terdapat 12 Reksa Dana saham yang memiliki kinerja positif, 40 Reksa Dana saham lainnya memiliki kinerja yang negatif. Sedangkan pada tahun 2013, terdapat 19 Reksa Dana saham dengan kinerja positif, 33 Reksa Dana saham lainnya memiliki kinerja negatif.

7. Berdasarkan metode $M^{2}$ pada tahun 2011, terdapat 19 Reksa Dana saham yang memiliki kinerja positif, 33 Reksa Dana saham memiliki kinerja negatif. Pada tahun 2012, terdapat 12 Reksa Dana saham yang memiliki kinerja positif, 40 Reksa Dana saham lainnya memiliki kinerja negatif. Pada tahun 2013, terdapat 23 Reksa Dana saham yang memiliki kinerja positif sedangkan 29 Reksa Dana saham lainnya memiliki kinerja yang negatif.

8. Berdasarkan metode Information Ratio pada tahun 2011, terdapat 19 Reksa Dana saham dengan kinerja 
positif dan 33 Reksa Dana saham dengan kinerja negatif. Pada tahun 2012, terdapat 12 Reksa Dana saham dengan kinerja positif dan 40 Reksa Dana saham dengan kinerja negatif. Pada tahun 2013, terdapat 19 Reksa Dana saham dengan kinerja positif dan 33 Reksa Dana saham dengan kinerja negatif.

9. Berdasarkan analisis yang dilakukan dalam penelitian ini metode terbaik untuk pengukuran kinerja Reksa Dana saham apabila investor ingin membandingkan secara langsung terhadap kinerja benchmark adalah metode $M$-Square $\left(M^{2}\right)$. Melalui metode $M$-Square investor dapat memperoleh gambaran secara jelas selisih return Reksa Dana saham yang dihasilkan terhadap return benchmark pada tingkat risiko yang sama. Metode M-Square juga menggunakan standar deviasi yang merupakan risiko keseluruhan yang berarti bahwa investor berasusmi portofolio yang dibentuk belum terdiversifikasi dengan baik sehingga risiko yang dianggap relevan adalah risiko sistematik dan risiko nonsistematik. Sedangkan, pada metode Jensen risiko yang digunakan hanya risiko sistematik (risiko pasar) dan metode Information Ratio hanya risiko nonsistematik (risiko khusus) sehingga, belum mencerminkan risiko secara keseluruhan.

10. Berdasarkan hasil perbandingan kinerja Reksa Dana saham dengan kinerja benchmark pada tahun 2011 menunjukkan bahwa terdapat 18 Reksa Dana saham yang mampu outperform. Pada tahun 2012, hasil perbandingan menunjukkan bahwa terdapat 13 Reksa Dana saham yang mampu outperform. Sedangkan pada tahun 2013, hasil perbandingan menunjukkan bahwa terdapat 16 Reksa Dana saham yang mampu outperform.

11. Berdasarkan hasil penelitian, tidak terdapat satupun Reksa Dana saham yang mampu konsisten memiliki kinerja positif selama periode penelitian dengan metode Sharpe, Treynor, Jensen, $M^{2}$ dan Information Ratio. Namun, terdapat 1 Reksa Dana saham yang memiliki status outperform secara konsisten selama tahun 2011, 2012 dan 2013 yaitu Reksa Dana saham Cipta Syariah Equity dari Manajer Investasi PT Cipta Dana Asset Management. 
Saran

Berdasarkan kesimpulan yang telah dipaparkan sebelumnya maka disampaikan beberapa saran sebagai berikut :

1. Bagi Investor

Investor sebaiknya memilih Reksa

Dana saham dengan kinerja positif dan memiliki status outperform terhadap kinerja benchmark ke dalam portofolio investasi mereka.

2. Bagi Peneliti Selanjutnya

Setiap metode dan benchmark yang digunakan akan menghasilkan penilaian yang berbeda-beda terutama pada peringkat kinerja terbaik. Peneliti selanjutnya dapat menggunakan metode lainnya seperti metode raw return, metode sortino atau snail trail dengan data yang lebih up to date sehingga hasil penelitian tersebut dapat dibandingkan dengan penelitian ini.

\section{DAFTAR PUSTAKA}

Amalia, Dewi dan Zaenal Arifin. (1999). Perbandingan Kinerja Reksa Dana; Periode sebelim Krisis dan Periode Krisis. Yogyakarta: Sinergi UII, Vol.2 dan No.1.

Hartono, Jogiyanto. (2010). Teori Portofolio dan Analisis Investasi. Yogyakarta: BPFEUGM.

Intan, Fitianing, R. Rustam dan Topowijono. (2010). Evaluasi Kinerja Reksa Dana Pendapatan Tetap berdasarkan Metode Sharpe,
Metode Treynor dan Metode Jensen.Jurnal Manajemen Keuangan.

Kuncoro, Mudrajat. (2007). Metode Kuantitatif, Teori dan Aplikasi untuk Bisnis dan Ekonomi, UPP STIM YKPN, Yogyakarta.

Manurung, A. H. (2006). Analisis Kinerja Reksa Dana dengan Menggunakan Metode Risk-Adjusted Return, Rasio Risiko dan Snail Trail.Usahawan No.9 Th XXXV September.

Manurung, A. H. (2008). Reksa Dana Investasiku. Jakarta: Kompas.

Prasetya,Ginting dan Bandi. (2010). Reksa Dana di Indonesia: Analisis Kebijakan Alokasi aset, Pemilihan Saham dan Tingkat Risiko.Akuntansi Keuangan dan Pasar Modal (AKPM).

Purnomo, C. K. (2007). Pengaruh Kebijakan Alokasi Aset dan pemilihan Sekuritas terhadap Kinerja Reksa Dana Syariah. Electronic copy available at: http://www.docstoc.com/docs/2926233 7.

Putri,Anindita Agus Purwanto. (2012). Analisis Kebijakan Alokasi Aset, Kinerja Manajerdan tingkat risiko terhadap kinerja Reksa Dana Saham di indonesia. Diponegoro Journal Of Accounting.

Rantetonding, S. (2002). Analisis Kinerja Reksa Dana dengan Metode Sharpe Periode 1998-2001.Semarang: Tesis, MM UNDIP, Tidak Dipublikasikan.

Santosa,Magdalena dan Amelina. (2012). Penilaian Produk Reksa Dana 
dengan Menggunakan

Perhitungan Jensen Alpha, Sharpe

Ratio, Treynor Ratio, M-Square, dan Information Ratio.Jurnal Manajemen, Vol. 12, November 2012.

Saraswati, N. (2006). Analisis Pengukuran Kinerja Reksa Dana Saham di Bursa Efek Jakarta.Program Sarjana Strata-1 Manajemen UII.

Siahaan, V. (2006). Menggunakan Metode Jensen dalam Pengukuran Kinerja Reksa Dana: Studi Kasus Tujuh Reksa Dana Saham. Jurnal Manajemen 2006

Simforianus dan Yanthi Hutagaol. (2008). Analisis Kinerja Reksa Dana Saham dengan Metode Raw Return, Sharpe, Treynor, Jensen dan Sortino. Journal of Applied Finance and Accounting (Vol. 1, No. 1, November 2008) Hlm 193-226.

Sugiyono. (2009). Metode Penelitian Bisnis. Bandung: Alfabeta bandung.

Sunariyah. (2004). Pengantar Pengetahuan Pasar Modal. Edisi Keempat. Yogyakarta: UPP AMP YKPN.

Tandelilin, Eduardus. (2001). Analisis Investasi dan Manajemen Portofolio. Yogyakarta: BPFE.

Wibowo, Satrio. (2005). Penilaian Kinerja Reksa Dana dengan Metode Jensen . Jurnal Manajemen Keuangan.

http://reksadana.danareksaonline.com/e dukasi/tentang-reksadana.aspx/diakses pada 23 Juni 2014 